\title{
Effects of pregrazing herbage mass in late spring on enteric methane emissions, dry matter intake, and milk production of dairy cows
}

\author{
C. Muñoz, ${ }^{* 1}$ P. A. Letelier,† E. M. Ungerfeld, $\ddagger$ J. M. Morales, ${ }^{*}$ S. Hube, ${ }^{*}$ and L. A. Pérez-Prieto* \\ *Instituto de Investigaciones Agropecuarias, INIA Remehue, Casilla 24-O, Osorno 5290000, Chile \\ †Escuela de Medicina Veterinaria, Facultad de Ciencias Silvoagropecuarias, Universidad Mayor, Camino La Pirámide №5750, Huechuraba, \\ Santiago 8580745, Chile \\ łInstituto de Investigaciones Agropecuarias, INIA Carillanca, Camino Cajón Vilcún km 10, Temuco 4780000, Chile
}

\section{ABSTRACT}

Few studies have examined the effects of fresh forage quality on enteric methane $\left(\mathrm{CH}_{4}\right)$ emissions of dairy cows under grazing conditions. The aim of the current study was to evaluate the effects of 2 contrasting forage qualities induced by different pregrazing herbage masses in late spring on enteric $\mathrm{CH}_{4}$ emissions and milk production of grazing dairy cows. The experiment was conducted as a crossover design with 24 lactating Holstein Friesian dairy cows randomly assigned to 1 of 2 treatments in 2 experimental periods. Each period had a duration of $3 \mathrm{wk}$ ( $2 \mathrm{wk}$ for diet adaptation and 1 wk for measurements), and the interval between them was 2 wk. Treatments consisted of 2 target pregrazing herbage masses $[2,200$ and $5,000 \mathrm{~kg}$ of dry matter $(\mathrm{DM}) /$ ha above $3 \mathrm{~cm}$ ], generated by different regrowth periods, corresponding to low (LHM) and high (HHM) herbage mass treatments, respectively. Daily herbage allowance (Lolium perenne) for both treatments was $20 \mathrm{~kg}$ of DM per cow measured above $3 \mathrm{~cm}$. Enteric $\mathrm{CH}_{4}$ emissions were individually determined during the last week of each period using the sulfur hexafluoride tracer technique. Daily herbage intakes by individual cows during the $\mathrm{CH}_{4}$ measurement weeks were estimated using the n-alkanes technique. During the $\mathrm{CH}_{4}$ measurement weeks, milk yield and body mass were determined twice daily, whereas milk composition was determined once in the week. The LHM pasture had a higher crude protein concentration, lower neutral detergent fiber and acid detergent fiber concentrations, and higher in vitro digestibility, with a lower proportion of ryegrass pseudostems, than the HHM pasture. Cows offered the LHM pasture had greater herbage $(+13 \%)$ and total DM $(+12 \%)$ intakes, increased milk $(+13 \%)$ and energy-corrected milk $(+11 \%)$ yields, and

Received January 20, 2016.

Accepted June 13, 2016.

${ }^{1}$ Corresponding author: camila.munoz@inia.cl tendencies toward higher milk protein $(+4.5 \%)$ and higher milk urea nitrogen $(+15 \%)$ concentrations than their counterparts offered the HHM pasture. No differences were found between treatments in total daily $\mathrm{CH}_{4}$ production. However, the LHM treatment reduced enteric $\mathrm{CH}_{4}$ emissions per unit of milk yield $(-11 \%)$ and enteric $\mathrm{CH}_{4}$ energy as a percentage of ingested gross energy $(-9 \%)$ and tended to reduce $\mathrm{CH}_{4}$ per unit of dry matter intake $(-8.2 \%)$ and energy-corrected milk yield $(-10 \%)$ compared with the HHM treatment. The results from this study suggest that a grazing management that favors better quality pasture, as was the case of the LHM pasture in late spring compared with the HHM pasture, increases milk production of grazing dairy cows and reduces enteric $\mathrm{CH}_{4}$ emissions per unit of milk produced, constituting a viable $\mathrm{CH}_{4}$ mitigation strategy.

Key words: herbage mass, grazing, forage quality, methane, dairy cow

\section{INTRODUCTION}

Enteric methane $\left(\mathrm{CH}_{4}\right)$ emissions from livestock have been under scrutiny due to their contribution to climate change. Methane is a potent greenhouse gas with a global warming potential that is 28 times that of $\mathrm{CO}_{2}$, on a 100-yr time frame (Intergovernmental Panel on Climate Change, 2013). Additionally, enteric $\mathrm{CH}_{4}$ released to the atmosphere represents feed energy that is lost, thus contributing to reduced livestock production efficiency. Ruminants lose between 2 and $12 \%$ of ingested gross energy as $\mathrm{CH}_{4}$ (Johnson and Johnson, 1995). Improvement in forage quality, and more specifically forage digestibility, has been investigated as a means for enteric $\mathrm{CH}_{4}$ mitigation (Martin et al., 2010; Hristov et al., 2013). Structural carbohydrates have been reported to be more methanogenic than soluble carbohydrates (Janssen, 2010). In ruminants with high feed intakes, reductions in enteric $\mathrm{CH}_{4}$ emissions per unit of intake with increased digestibility of feeds have 
been reported (Hristov et al., 2013). Potential enteric $\mathrm{CH}_{4}$ reductions obtained with improved forage quality would be mediated by increased concentration of soluble carbohydrates and linolenic acid (Martin et al., 2010). Greater digestibility is associated with a fermentation profile in the rumen that is unfavorable to $\mathrm{CH}_{4}$ production. Furthermore, a more digestible feed is associated with greater intake and production, diluting maintenance energy requirements and resulting in less $\mathrm{CH}_{4}$ per unit of animal product (Hristov et al., 2013). Much of the work for evaluating the effects of feed quality on $\mathrm{CH}_{4}$ emissions has been carried out with diets based on concentrates and conserved forages (Yan et al., 2000; Hart et al., 2015). Research studies based on fresh forages are scarcer, and grazing studies are even more so (Lassey et al., 1997; Wims et al., 2010). In the latter, the relationship between forage quality and $\mathrm{CH}_{4}$ emissions has been contradictory. For example, at similar intake levels, enteric $\mathrm{CH}_{4}$ energy losses from cows grazing pasture in summer were higher than in spring, and this finding was attributed to grass maturation (Robertson and Waghorn, 2002). In contrast, Pinares-Patiño et al. (2003) reported that the proportion of gross energy intake loss as $\mathrm{CH}_{4}$ in beef cattle did not differ with timothy pasture grazed at 4 stages of maturity.

In the dairy production systems of southern Chile, grazing management is a key factor to finding the balance between quality and quantity of fresh grazed forages. In general, greater nutrient quality and digestibility of forages is positively correlated with reduced $\mathrm{CH}_{4}$ emissions (Hristov et al., 2013). Forage quality is in turn negatively associated with maturity. As the growing season progresses, forages go through different stages of maturity, changing from young living tissue to senescent material, with a concomitant decrease in digestibility. Digestibility changes that affect the feeding value of forages are generally associated with changes in the quantity of green leaf, mature stem, and senescent material (Holmes et al., 1992), and forage composition can be affected by grazing management. Pasture characteristics that determine forage quality, such as pregrazing herbage mass and regrowth period of pasture, affect herbage digestibility, intake and milk production (Stakelum and Dillon, 2004; McEvoy et al., 2009; Curran et al., 2010), and enteric $\mathrm{CH}_{4}$ emissions (Wims et al., 2010). In southern Chile, forage production peaks in mid to late spring. At that time of the year, milk production relies mostly on pastures with little supplementation. Thus, changes in pasture quality are thought to be more likely to influence animal performance and methane production at this time of the year. The aim of this experiment was to evaluate the effects of pregrazing herbage mass on enteric $\mathrm{CH}_{4}$ emissions, herbage intake, and milk production and composition of dairy cows during mid to late spring under the grazing conditions of southern Chile. We hypothesized that increasing the DM digestibility of fresh forage through grazing a low herbage mass compared with a high herbage mass pasture in late spring would result in lower enteric $\mathrm{CH}_{4}$ emissions per unit of milk yield.

\section{MATERIALS AND METHODS}

The experiment was conducted at Instituto de Investigaciones Agropecuarias (INIA), research farm Remehue $\left(40^{\circ} 31^{\prime} \mathrm{S} ; 73^{\circ} 03^{\prime} \mathrm{W}\right.$ and $65 \mathrm{~m}$ above mean sea level, Osorno, Chile) from October to December 2013. All procedures involving animals were performed in accordance with the requirements of the Chilean Law 20380 on Animal Protection and with the approval of the INIA Bioethics Committee.

\section{Animals, Experimental Design, and Treatments}

Twenty-four multiparous Holstein Friesian dairy cows with an initial mean body mass of $554 \pm 39.3 \mathrm{~kg}$ were used in the study. Two weeks before the beginning of the study, all cows grazed as a single herd on a perennial ryegrass (Lolium perenne)-based pasture and received $2 \mathrm{~kg}$ (fresh basis) of a commercial concentrate daily, which was offered during milking. The cows were first blocked by pre-experimental milk yield (31.1 \pm $4.0 \mathrm{~kg} / \mathrm{d}$ ) into 2 groups. Within each group, cows were paired based on their calving dates $(113 \pm 19.1 \mathrm{DIM})$ and within pairs randomly allocated to 1 of 2 dietary treatments. No initial differences existed between the groups in DIM $(P=0.84)$, milk yield $(P=0.84)$, body mass $(P=0.17)$, or age $(P=0.79)$.

A crossover design with 2 treatments and 2 feeding periods was used for the present study. Each feeding period had a 3 -wk duration, which included $14 \mathrm{~d}$ of diet adaptation, followed by $7 \mathrm{~d}$ of $\mathrm{CH}_{4}$ and other animal data collection. Treatments consisted of 2 target levels of pregrazing herbage mass: $2,200 \mathrm{~kg}$ of $\mathrm{DM} /$ ha above $3 \mathrm{~cm}$ (low herbage mass, LHM) and $5,000 \mathrm{~kg}$ of DM/ ha above $3 \mathrm{~cm}$ (high herbage mass, HHM). Cows on both treatments were offered the same total herbage allowance of $20 \mathrm{~kg}$ of DM above $3 \mathrm{~cm}$ per animal and per day, which is representative of temperate production systems in late spring. Similar herbage allowances per animal were obtained by adjusting the grazing surface of each treatment according to their pregrazing herbage mass. Between the 2 experimental periods, the cows grazed a nonexperimental pasture as a single herd for 2 
wk to allow for herbage regrowth on the experimental plots and to reduce possible carryover effects of the first experimental period. Grass was not cut between the periods. The management of the experimental pasture between periods is described in the following section. In addition to their allocated dietary forage treatment, all cows received an additional $2 \mathrm{~kg}$ of concentrate (fresh basis) daily offered in 2 equal meals by automatic parlor feeders during milking. Observations were made to confirm that concentrate was not refused. The pelleted commercial concentrate mixture offered (12.32, Concentrados Cisternas, Osorno, Chile) contained (g/ $\mathrm{kg}$, fresh basis): steam-rolled corn (333), ground corn (210), rolled barley (143), wheat bran (133), dried distillers grains with solubles (48), ground beans (47), rice bran (38), and a standard vitamin and mineral supplement (48).

\section{Pasture and Grazing Management}

The study was conducted during the herbage stem elongation period (from October 28 to November 16 for period 1 and December 2-21 for period 2), which is the time of the year when milk production systems rely the most on grazed forage. A total of 6 ha of predominantly perennial ryegrass pasture was available for the study. The area had been sown 2 yr earlier and was subdivided into 12 subpaddocks of similar size (6 subpaddocks per treatment). The target herbage masses for the LHM and HHM treatments were prepared in adjacent subpaddocks by allowing different sward regrowth periods through pre-experimental grazing management in early spring. For the pre-experimental grazing management, pastures were grazed by a nonexperimental dairy herd to a postgrazing compressed height of $5 \mathrm{~cm}$ measured with a rising platemeter (diameter $36.5 \mathrm{~cm}$ and $3.0 \mathrm{~kg} /$ $\mathrm{m}^{2}$; F200 Farmworks, Feilding, New Zealand). After a few days, when the compressed height reached $11 \mathrm{~cm}$, the LHM subpaddocks were again grazed by the nonexperimental dairy herd to a postgrazing compressed height of $5 \mathrm{~cm}$. Pasture in paddocks was then allowed to grow until reaching the target herbage masses. The regrowth period averaged 24 (SD 9.1) and 43 (SD 6.7) days for the LHM and HHM treatments, respectively, in the first period. The same area was used in the second period of the study (i.e., the same paddocks were grazed twice during the experiment). For the second period, grazed subpaddocks were prepared successively using the same pre-experimental grazing procedure as previously described. Most treatments were applied in the same plots as in period 1 (i.e., LHM and HHM plots were similar in both periods). One exception was a subpaddock corresponding to the LHM treatment that was not grazed in period 1 , and that was allowed to continue growing and was set up as a HHM subpaddock in period 2. In period 2, the regrowth periods averaged 31 (SD 8.1) and 46 (SD 4.0) days for the LHM and HHM treatments, respectively. During the experiment, cows in each treatment group grazed adjacent subpaddocks under strip grazing using temporary electric fencing. The herbage area allocated daily to each treatment group was adjusted by daily estimates of the pregrazing herbage mass, as described in the following section. On average, animals grazed each subpaddock between 4 and $6 \mathrm{~d}$, depending on herbage mass. The daily fresh herbage allowance was offered to the cows every morning after milking and access to the previous day's grazing area was restricted through the use of back-fencing. All cows had free access to fresh water for the duration of the study.

\section{Herbage Measurements}

Herbage mass and allowance per animal were measured above $3 \mathrm{~cm}$ throughout the study because herbage mass and allowance measured above $2.5 \mathrm{~cm}$ adequately estimates the herbage actually available to cows (Pérez-Prieto et al., 2012). Pregrazing herbage mass was measured once a week during the adaptation phase of each period and twice weekly during the $\mathrm{CH}_{4}$ measurement periods. Pregrazing herbage mass was measured in 4 rectangular $0.5-\mathrm{m}^{2}(50 \times 100 \mathrm{~cm})$ framed plots selected at random in each subpaddock. In each plot, the herbage was cut above $3 \mathrm{~cm}$ using a handheld electric clipper, collected in plastic bags, labeled, and weighed. A 200-g subsample was oven-dried $\left(60^{\circ} \mathrm{C}\right.$ for $48 \mathrm{~h}$ ) to determine DM concentration. To calculate the herbage height in each plot, 4 measurements of the sward heights were made per plot with a rising platemeter before and after cutting. Sward bulk density was calculated on each plot by dividing herbage mass by cutting depth.

Pregrazing and postgrazing compressed herbage heights were also measured daily for each treatment using a rising platemeter (previously described) with 100 measurements per treatment made at random while crossing in zigzag across each grazing area. For each treatment, pregrazing herbage mass was calculated daily by multiplying the sward bulk density by the pregrazing sward height minus $3 \mathrm{~cm}$. The daily grazing area to be offered to each treatment group was then calculated and adjusted according to the predetermined herbage allowance.

The morphological composition of the pasture was determined from 2 samples of herbage per treatment harvested during the $\mathrm{CH}_{4}$ measurement weeks. In the 
pregrazing herbage strip, 15 handfuls of herbage were randomly selected and cut with scissors at ground level, preserving the vertical distribution of the herbage. Handfuls were combined and placed in plastic bags and stored at $-20^{\circ} \mathrm{C}$. Mean compressed postgrazing sward height for the study was $6.3 \mathrm{~cm}$, and the herbage samples were therefore cut at $8 \mathrm{~cm}$ to reflect the average postgrazing extended tiller sward height (Ribeiro Filho et al., 2005), resulting in an upper sward horizon representative of the herbage removed by the cows and consequently the diet ingested. The upper layer was manually separated into ryegrass lamina, ryegrass pseudostem, clover, dead material, and other plant species. Each component was oven-dried $\left(60^{\circ} \mathrm{C}\right.$ for $\left.48 \mathrm{~h}\right)$ and the proportion of each component was calculated on a DM basis.

During $\mathrm{CH}_{4}$ measurement weeks, 6 herbage samples per treatment ( 1 per day for $6 \mathrm{~d}$ ) representative of the herbage grazed were cut by hand from the pregrazing herbage strip at the postgrazing height of the previous day to determine the herbage chemical composition. In addition, a sample of concentrate was taken daily during these weeks and pooled weekly to determine the chemical composition.

\section{Animal Measurements}

Throughout the study, cows were milked twice daily at around 0530 and $1600 \mathrm{~h}$, with individual milk yields recorded automatically at each milking. Milk composition (fat, protein, lactose, and MUN) was determined once per period from samples taken at 2 consecutive milkings from the same day using a MilkoScan instrument (Foss Electric, Hillerød, Denmark). The milk yield and composition reported correspond to the $\mathrm{CH}_{4}$ measurement weeks only. Energy-corrected milk yield was calculated using Equations [1] and [2] (Tyrrell and Reid, 1965):

$$
\text { ECM yield }(\mathrm{kg} / \mathrm{d})=\mathrm{MY}(\mathrm{kg} / \mathrm{d}) \times \operatorname{MEC}(\mathrm{MJ} / \mathrm{kg}) / 3.1 \text {, }
$$

where $\mathrm{MY}=$ milk yield, $\mathrm{MEC}=$ milk energy content, and 3.1 is the energy content $(\mathrm{MJ} / \mathrm{kg}$ ) of standard milk for Holstein Friesian cows with $4 \%$ fat, $3.2 \% \mathrm{CP}$, and $4.8 \%$ lactose.

$$
\begin{aligned}
& \text { Milk energy content }(\mathrm{MJ} / \mathrm{kg})=(0.0384 \times \text { fat }) \\
& +(0.0223 \times \mathrm{CP})+(0.0199 \times \text { lactose })-0.108
\end{aligned}
$$

Cow body mass was recorded automatically twice daily after every milking, with mean body mass calculated for each week of the study. Body mass change per period was calculated using linear regression.

Herbage intake was measured from d 15 to 19 of each period (during $\mathrm{CH}_{4}$ measurement weeks) using the double n-alkane technique (Mayes et al., 1986). For 12 d (from d 8 to 19 of each period), animals were dosed twice daily, after the morning and before the evening milking, with a cellulose stopper (Carl Roth, GmbH, Karlsruhe, Germany) containing $416 \pm 38 \mathrm{mg}$ of the alkane $\mathrm{C}_{32}$ (dotriacontane). From the afternoon of $\mathrm{d}$ 15 to the morning of $\mathrm{d} 20$ of each period, fresh fecal samples were collected from each cow twice daily either immediately after voiding feces or via rectal grab and stored at $4^{\circ} \mathrm{C}$. For each period, samples were pooled by cow, subsampled, and dried for $48 \mathrm{~h}$ at $60^{\circ} \mathrm{C}$. Samples were then milled through a 1-mm sieve and stored for analysis of n-alkanes $\mathrm{C}_{31}, \mathrm{C}_{32}$, and $\mathrm{C}_{33}$. During the feces collection period, a sample of the concentrate offered was retained daily, pooled per period, subsampled, oven-dried at $60^{\circ} \mathrm{C}$ for $48 \mathrm{~h}$, milled (as previously described), and analyzed for $\mathrm{C}_{31}, \mathrm{C}_{32}$, and $\mathrm{C}_{33}$. Additionally, during the feces collection period, 1 herbage sample representative of the herbage grazed was taken daily for each treatment from the pregrazing herbage strip by cutting herbage by hand at the postgrazing height of the previous day. Following collection, these samples were washed with fresh water and frozen at $-20^{\circ} \mathrm{C}$, pooled by treatment, freeze-dried, and milled through a 1-mm screen for determination of n-alkanes $\mathrm{C}_{31}, \mathrm{C}_{32}$, and $\mathrm{C}_{33}$. The determination of n-alkanes in feces, herbage, and concentrate samples followed the methodology reported by Dove and Mayes (2006). Herbage intakes were estimated based on the ratio of feedstuffs natural $\mathrm{C}_{33}$ alkane to dosed $\mathrm{C}_{32}$ alkane using the equation of Mayes et al. (1986).

\section{Enteric $\mathrm{CH}_{4}$ Emission}

During the last $7 \mathrm{~d}$ of each period, the enteric $\mathrm{CH}_{4}$ emissions from individual animals were estimated using the sulfur hexafluoride $\left(\mathrm{SF}_{6}\right)$ tracer gas technique (Johnson et al., 2007). Methane sampling equipment and procedures were as reported by Muñoz et al. (2015) with the following modifications. During sampling, canisters with a postcollection pressure outside the range of 50 to $67 \mathrm{kPa}$ below atmospheric pressure were discarded. After sampling, canisters were overpressurized with high-purity nitrogen $\left(\mathrm{N}_{2}\right)$ to approximately $20 \mathrm{kPa}$ above atmospheric pressure before gas concentration analysis. Background $\mathrm{SF}_{6}$ and $\mathrm{CH}_{4}$ concentrations were determined using 3 gas sampling sets (canister and headcollar) placed daily in a fixed position outside the perimeter of the subpaddocks, preferably upwind and 
out of the reach of the experimental cattle, at around $50 \mathrm{~cm}$ above ground level using electric fencing posts. The permeation rate of the brass tubes containing $\mathrm{SF}_{6}$ gas used in this study ranged from 2.45 to $4.80 \mathrm{mg} / \mathrm{d}$, with a mean of $3.74 \pm 0.76 \mathrm{mg} / \mathrm{d}$.

Methane analytical methods and calculations were as reported by Muñoz et al. (2015) with modifications as described below. The $\mathrm{CH}_{4}$ column was a Carboxen 1010 plot, $15 \mathrm{~m} \times 0.32-\mathrm{mm}$ internal diameter (Supelco, Sigma-Aldrich, St. Louis, MO), and the column used for $\mathrm{SF}_{6}$ analysis was an Elite-GC GS Molesieve column, $30 \mathrm{~m} \times 0.53-\mathrm{mm}$ ID $\times 50-\mu \mathrm{m}$ film thickness (Perkin Elmer, Waltham, MA). The operating temperatures of the injector and oven were 200 and $50^{\circ} \mathrm{C}$, respectively. The GC was calibrated using 3 gas standards of known concentrations (Scott-Marrin Inc., Riverside, CA).

Out of a total of 336 enteric $\mathrm{CH}_{4}$ samples (24 cows $\times$ $7 \mathrm{~d} \times 2$ periods), 22 samples were lost during sampling because of breakages or disconnections of the fitting that joins the sampling line with the canister, 18 were eliminated because of postsampling pressure being outside the acceptable range, and 9 samples were lost during manipulation in the laboratory. Thus, reported results are based on total of 287 samples, 71 and 68 samples in period 1 and 75 and 73 samples in period 2 for the LHM and HHM treatments, respectively.

\section{Chemical Analyses}

All chemical analyses were conducted at Laboratorio de Nutrición Animal y Ambiente, INIA Remehue (NchISO 17025), with the exception of gross energy, which was determined at Laboratorio de Nutrición Animal, Universidad Austral de Chile, Valdivia. Herbage and concentrate samples were thoroughly homogenized, dried at $60^{\circ} \mathrm{C}$ for $48 \mathrm{~h}$, ground through a $1-\mathrm{mm}$ sieve, and then stored in plastic bags at room temperature until chemical analyses. Samples were analyzed for DM, $\mathrm{CP}, \mathrm{NDF}, \mathrm{ADF}$, and ash concentrations according to the procedures outlined by the AOAC International (1995). Dry matter digestibility was determined in vitro as by Goering and Van Soest (1970). Gross energy was determined by oxygen bomb calorimetry (Bateman, 1970). All samples were analyzed in duplicate.

\section{Statistical Analyses}

Sward characteristics and herbage chemical composition were analyzed with ANOVA including the fixed effects of treatment and period:

$$
\begin{aligned}
\text { response }_{i j k} & =\text { overall mean } \text { treatment }_{i} \\
& +\operatorname{period}_{j}+\text { residual }_{i j k},
\end{aligned}
$$

where $i$ corresponds to the LHM or HHM treatment and $j$ corresponds to period 1 or period 2 .

Herbage intake, milk production and composition, body mass change, and $\mathrm{CH}_{4}$ emission were analyzed with a mixed model including the fixed effects of treatment and period, and the random effect of the cow:

$$
\begin{aligned}
& \text { response }_{i j k l}=\text { overall mean }+ \text { treatment }_{i} \\
& +\operatorname{period}_{j}+\operatorname{cow}_{k}(\text { random })+\text { residual }_{i j k l}
\end{aligned}
$$

where $i$ corresponds to the LHM or HHM treatment, $j$ corresponds to period 1 or period 2 , and $k$ corresponds to each cow.

Significance was declared at $P<0.05$ and tendencies at $0.05 \leq P \leq 0.10$. All statistical analyses were conducted using JMP 12.1.0 (SAS Institute Inc., Cary, $\mathrm{NC})$.

\section{RESULTS}

\section{Herbage and Concentrate Chemical Composition}

The concentrate contained $894 \mathrm{~g}$ of DM/kg, and each kilogram of DM contained $137 \mathrm{~g}$ of $\mathrm{CP}, 16.5 \mathrm{MJ}$ of gross energy, $210 \mathrm{~g}$ of NDF, $71 \mathrm{~g}$ of ADF, $97 \mathrm{~g}$ of ash, and $881 \mathrm{~g}$ of digestible DM. The chemical composition of the herbage offered across both periods is presented in Table 1. The LHM pasture tended to have a lower DM concentration $(P=0.10)$ than the HHM pasture. The concentration of CP $(P<0.001)$ was higher and the concentrations of NDF and ADF were lower $(P<$ 0.001) in the LHM pasture than in the HHM pasture. The LHM pasture tended to have a higher gross energy $(P=0.07)$ content and had a higher in vitro DM digestibility $(P<0.001)$ than the HHM pasture. No differences in ash concentration were detected between treatments $(P=0.74)$. Herbage DM $(P<0.001)$ and ADF $(P=0.05)$ concentrations were lower in period 1 than in period 2 . The herbage $\mathrm{CP}$ concentration $(P=$ $0.01)$, ash concentration $(P<0.001)$, and in vitro DM digestibility $(P<0.001)$ were higher in period 1 than in period 2. Herbage gross energy $(P=0.88)$ and NDF $(P$ $=0.90)$ concentrations did not differ between periods.

\section{Pasture Measurements}

The effects of pregrazing herbage mass on sward characteristics are shown in Table 2. Pregrazing sward height $(P<0.001)$, postgrazing sward height $(P<$ $0.001)$, and herbage mass $(P<0.001)$ were lower in the LHM pasture than in the HHM pasture. Herbage allowance was similar between treatments $(P=0.50)$. Cows 
Table 1. Effects of pregrazing herbage mass on DM concentration and chemical composition $(\mathrm{g} / \mathrm{kg}$ of DM unless otherwise stated) of herbage offered to strip-grazing dairy cows

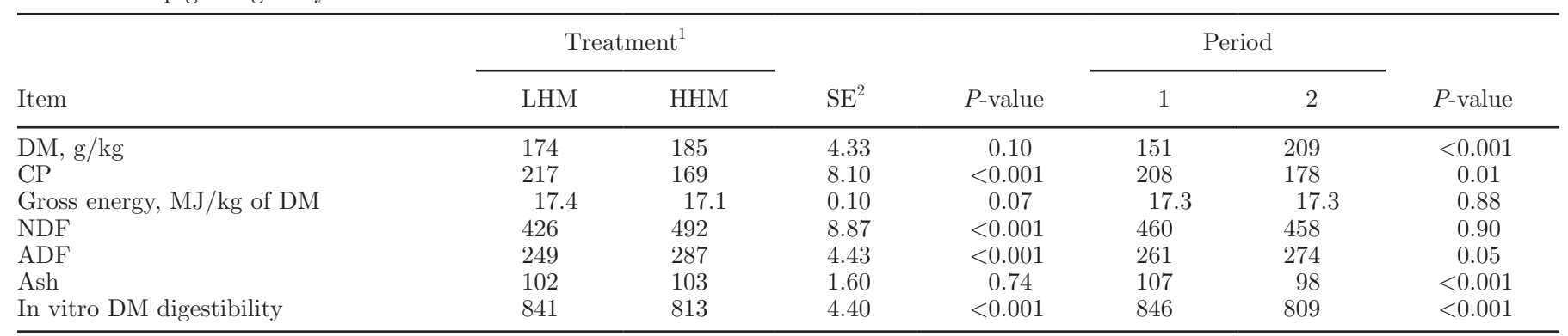

${ }^{1} \mathrm{LHM}=$ low herbage mass; HHM $=$ high herbage mass.

${ }^{2}$ The SE reported corresponds to both treatment and period effects.

grazing the LHM pasture were allocated a greater grazing area per day than cows grazing the HHM pasture $(P<0.001)$. In the first period of the study, pregrazing $(P<0.001)$ and postgrazing herbage height $(P<$ $0.001)$ were higher, and herbage allowance was lower $(P$ $=0.01$ ), than in the second period of the study. No differences existed between periods in pregrazing herbage mass $(P=0.21)$ or daily grazed area $(P=0.69)$. With regard to the morphological composition of pasture, the LHM treatment had a lower ryegrass pseudostem proportion $(P=0.01)$ than the HHM treatment, and no differences were found in the proportions of ryegrass lamina $(P=0.12)$, clover $(P=0.78)$, other species $(P$ $=0.63)$, or dead material $(P=0.57)$. Ryegrass pseudostem proportion was smaller $(P=0.01)$ and the presence of other species was greater $(P=0.01)$ in period 2 than in period 1 . No differences were found in ryegrass lamina proportion $(P=0.12)$, clover proportion $(P=$ $0.58)$, or dead material proportion $(P=0.44)$ between periods.

\section{Animal Performance and Herbage Intake}

The effects of pregrazing herbage mass on animal performance are shown in Table 3 . Cows grazing the LHM pasture had higher milk $(P<0.001)$ and ECM yields $(P=0.01)$, tended to have higher milk protein concentration $(P=0.07)$, and had higher MUN concentration $(P<0.001)$ than cows grazing the HHM pasture. Pregrazing herbage mass did not affect the concentration of milk fat $(P=0.42)$, milk lactose $(P$ $=0.26$ ), or milk solids (fat plus protein; $P=0.77$ ). In period 1 of the study, milk yield $(P<0.001)$, ECM yield $(P<0.001)$, milk fat $(P<0.001)$, milk lactose $(P$ $<0.001$ ), and milk solids (fat plus protein; $P=0.001$ ) were higher and MUN was lower $(P<0.001)$ than in period 2. Period had no effect on milk protein concentration $(P=0.48)$. Neither treatments $(P=0.98)$ nor period $(P=0.18)$ affected body mass change. The effects of pregrazing herbage mass on herbage intake are shown in Table 4. Cows grazing the LHM pasture

Table 2. Effects of pregrazing herbage mass on sward height, herbage mass, herbage allowance, grazed area, and morphological composition of forages offered to strip-grazing dairy cows

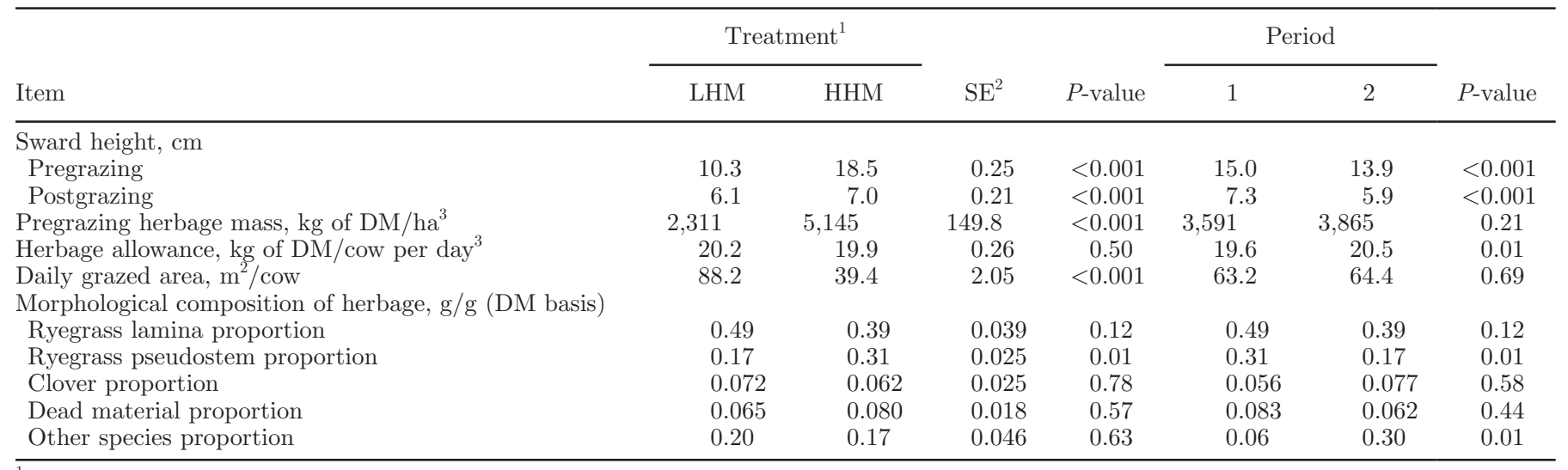

${ }^{1} \mathrm{LHM}=$ low herbage mass; HHM $=$ high herbage mass.

${ }^{2}$ The SE reported corresponds to both treatment and period effects.

${ }^{3}$ Measured $3 \mathrm{~cm}$ above ground level. 
Table 3. Effects of pregrazing herbage mass on daily milk yield, output of milk constituents, and body mass change of strip-grazing dairy cows

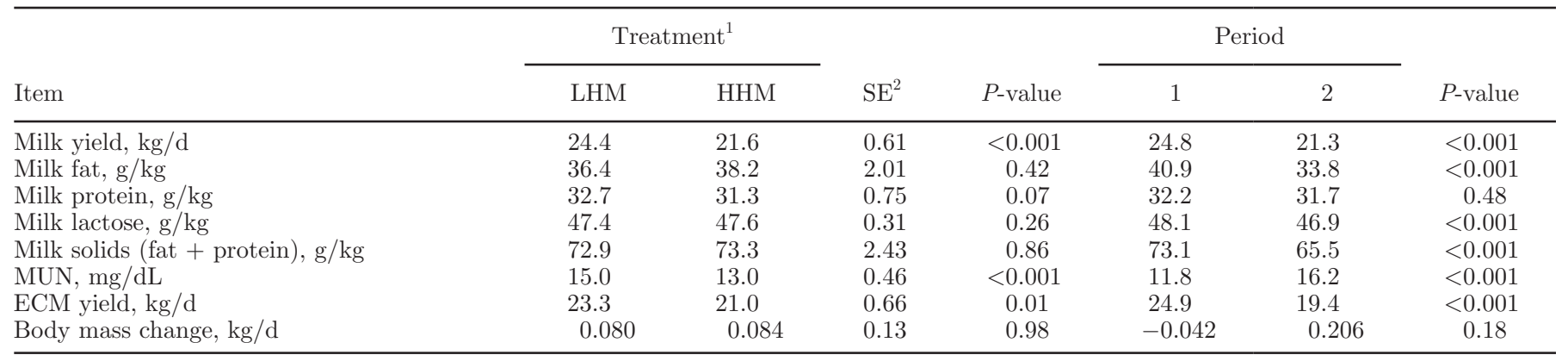

${ }^{1} \mathrm{LHM}=$ low herbage mass; HHM $=$ high herbage mass.

${ }^{2}$ The SE reported corresponds to both treatment and period effects.

had a higher herbage intake $(P<0.001)$ and total DMI $(P<0.001)$ than their counterparts grazing the HHM pasture. Herbage intake $(P=0.81)$ or total DMI $(P=$ 0.85 ) did not differ between the 2 periods of the study.

\section{Enteric $\mathrm{CH}_{4}$ Emissions}

The effects of pregrazing herbage mass on enteric $\mathrm{CH}_{4}$ emissions are shown in Table 4. Total $\mathrm{CH}_{4}$ emissions $(P$ $=0.85)$ did not differ between cows grazing the LHM or HHM pastures, with an average value of $322 \pm 34.6$ $\mathrm{g} / \mathrm{d}$. Cows grazing the LHM pasture tended to produce less $\mathrm{CH}_{4}$ per kilogram of feed intake $(P=0.05)$ and per kilogram of ECM yield $(P=0.07)$ and produced less $\mathrm{CH}_{4}$ per kilogram of milk $(P=0.01)$ compared with their counterparts grazing the HHM pasture. Enteric $\mathrm{CH}_{4}$ energy as a percentage of gross energy intake $\left(\mathrm{Y}_{\mathrm{m}}\right)$ was higher in the cows grazing the HHM pasture than in the cows grazing the LHM pasture $(P=0.03)$. Total $\mathrm{CH}_{4}$ emissions $(P=0.01), \mathrm{CH}_{4}$ per unit of DMI $(P=$ $0.03), \mathrm{CH}_{4}$ per unit of milk yield $(P<0.001), \mathrm{CH}_{4}$ per unit of ECM yield $(P<0.001)$, and $\mathrm{Y}_{\mathrm{m}}(P=0.03)$ in- creased in period 2 of the study, compared with period 1.

\section{DISCUSSION}

The aim of this study was to investigate if improving forage quality through maintaining pastures with lower pregrazing herbage mass during late spring could reduce enteric $\mathrm{CH}_{4}$ emissions and increase milk production of dairy cows. Our results demonstrate that dairy cows grazing LHM pasture in late spring had increased ECM yield and reduced enteric $\mathrm{CH}_{4}$ emissions per unit of milk yield compared with their counterparts grazing HHM pasture. These differences were mediated through increased herbage intakes of better quality forage and improved efficiency of gross energy use.

\section{Herbage Characteristics}

Herbage grazing management has a strong impact on forage quality. In the present study, the treatments imposed resulted in 2 contrasting herbage masses $(2,800$

Table 4. Effects of pregrazing herbage mass on feed intake and enteric methane $\left(\mathrm{CH}_{4}\right)$ emission of strip-grazing dairy cows

\begin{tabular}{|c|c|c|c|c|c|c|c|}
\hline \multirow[b]{2}{*}{ Item } & \multicolumn{2}{|c|}{ Treatment $^{1}$} & \multirow[b]{2}{*}{$\mathrm{SE}^{2}$} & \multirow[b]{2}{*}{$P$-value } & \multicolumn{2}{|c|}{ Period } & \multirow[b]{2}{*}{$P$-value } \\
\hline & LHM & HHM & & & 1 & 2 & \\
\hline \multicolumn{8}{|l|}{ DMI, $\mathrm{kg} / \mathrm{d}$} \\
\hline Herbage & 13.7 & 12.1 & 0.36 & $<0.001$ & 13.0 & 12.8 & 0.81 \\
\hline Concentrate & 1.8 & 1.8 & - & - & 1.8 & 1.8 & - \\
\hline Total & 15.5 & 13.9 & 0.36 & $<0.001$ & 14.7 & 14.6 & 0.85 \\
\hline \multicolumn{8}{|l|}{ Enteric $\mathrm{CH}_{4}$ emissions } \\
\hline $\mathrm{CH}_{4} \mathrm{~g} / \mathrm{d}$ & 323 & 321 & 10.0 & 0.85 & 309 & 336 & 0.01 \\
\hline $\mathrm{CH}_{4} \mathrm{~g} / \mathrm{kg}$ of $\mathrm{DMI}$ & 21.3 & 23.2 & 0.86 & 0.05 & 21.2 & 23.4 & 0.03 \\
\hline $\mathrm{CH}_{4} \mathrm{~g} / \mathrm{kg}$ of milk yield & 13.6 & 15.3 & 0.64 & 0.01 & 12.7 & 16.2 & $<0.001$ \\
\hline $\mathrm{CH}_{4} \mathrm{~g} / \mathrm{kg}$ of ECM yield & 14.3 & 15.9 & 0.70 & 0.07 & 12.7 & 17.6 & $<0.001$ \\
\hline $\mathrm{Y}_{\mathrm{m}}{ }^{3}, \%$ of $\mathrm{GE}$ & 6.8 & 7.5 & 0.28 & 0.03 & 6.8 & 7.5 & 0.03 \\
\hline
\end{tabular}


$\mathrm{kg}$ of DM/ha difference between treatments). The pregrazing herbage mass obtained in the LHM treatment $(\sim 2,300 \mathrm{~kg}$ of $\mathrm{DM} / \mathrm{ha})$ was similar to LHM treatments measured $>3 \mathrm{~cm}$ of previous studies (Stakelum and Dillon, 2004; Pérez-Prieto et al., 2012). The pregrazing herbage mass of the HHM treatment $(\sim 5,100 \mathrm{~kg}$ of $\mathrm{DM} / \mathrm{ha}$ ) was somewhat higher than other high herbage mass studies, for example, 4,200 kg of DM/ha (PérezPrieto et al., 2012) and 3,700 kg of DM/ha (Stakelum and Dillon, 2004). In particular, the former study used rising platemeter targets similar to the present study, but they were shorter in duration and were conducted earlier in the season our study, thus before the start of the reproductive stage of pasture. Because our aim was to obtain contrasting herbage qualities, a higher herbage mass was necessary.

The findings of the present study indicate that the quality of the LHM pasture was better than that of the HHM pasture. This finding is in agreement with Hoogendoorn et al. (1992) who reported that low herbage mass swards in late spring and summer contained lower amounts of grass stems and senescent material, but higher concentrations of green leaf, clover, and digestible nutrients, than high herbage mass swards in the same season. Similar findings have been reported by O'Donovan and Delaby (2008). The 30\% increase in "other species" observed in the second period of the study most likely corresponds to weeds because it is not uncommon for nonirrigated pastures to manifest an increase in weeds during their reproductive stage. Overall, the LHM pasture had better quality and a shorter rotation length than the HHM pasture, although the surface grazed by the animals was more than double. The practical implications of these results in a farming system are difficult to extrapolate. Decisions regarding grazing management have practical and economic implications and must therefore be considered carefully to strike the right balance between the quality and quantity of fresh forage and its availability for silage- or hay-making, for example.

\section{Herbage Intake and Milk Yield and Composition}

The dairy cows grazing LHM pasture had greater herbage DMI and milk yield than cows grazing HHM pasture. This finding contrasts with Pérez-Prieto et al. (2012) who reported that herbage intake was not affected by herbage mass when herbage mass was measured above 2 to $3 \mathrm{~cm}$. However, Pérez-Prieto et al. (2012) carried out their experiment earlier in the season with pastures in vegetative stage before initiation of stem elongation and lignification and low and high herbage masses were consequently of similar quality with no differences in $\mathrm{OM}$ digestibility. Further, in the metaanalysis by Pérez-Prieto and Delagarde (2012), studies in which herbage mass changes did not affect pasture quality showed that herbage mass had no effect on either pasture intake or milk production. This outcome is again most likely related to the time of year of the studies and the treatment durations, which in turn determine pasture maturity and composition. In general, greater intakes can be expected with better quality forage because voluntary intake is negatively related to forage cell-wall concentration (Jung and Allen, 1995).

The accurate determination of grazed herbage intakes by individual animals when evaluating production efficiency and enteric $\mathrm{CH}_{4}$ emissions is a major challenge for grazing studies. Individual grazed herbage intake in the present study was estimated using the nalkane tracer technique. Feed DMI was also estimated using energy requirement models (Agricultural and Food Research Council, 1993; Agnew et al., 2004) in which the nutritional energy requirements of body mass maintenance, gain, and lactation were calculated (data not shown). The mean herbage intake estimation calculated using the energy requirement models was $15.1 \mathrm{~kg}$ of $\mathrm{DM} /$ cow with no differences between herbage mass treatments. Although slightly lower, the herbage intake results measured with the n-alkane technique reflect the milk yield response observed in the present study (higher intake and milk production in the LHM treatment), most likely associated with the higher quality and better nutritive value of the forage.

In the present study, milk protein concentration tended to be greater in the LHM than in the HHM treatment. This finding is most likely related to lower intake of rumen fermentable carbohydrates in the HHM treatment, which could result in a decreased propionate supply for gluconeogenesis. This situation could have resulted in increased use of amino acids for gluconeogenesis in the HHM treatment, thereby reducing the supply of amino acids for milk protein synthesis (Hoffman et al., 1997).

\section{Enteric $\mathrm{CH}_{4}$ Emissions}

In this study, despite LHM cows having greater herbage intakes than HHM cows, no differences in total enteric $\mathrm{CH}_{4}$ emissions were observed, a result that seems to be due to the better feeding value of the LHM pasture. In the study of Hammond et al. (2013), 0.87 of the variation in total enteric $\mathrm{CH}_{4}$ emissions of grazing sheep was predicted by OM intake, and the relationships between forage chemical composition and total $\mathrm{CH}_{4}$ emissions and $\mathrm{CH}_{4}$ yield $(\mathrm{g} / \mathrm{kg}$ of DM intake) were weak. Similarly, diet chemical composition only 
predicted 0.13 of the variation in $\mathrm{CH}_{4}$ yield from cattle fed ryegrasses with a wide composition range (Hammond et al., 2009). Reductions in $\mathrm{CH}_{4}$ emissions both per animal and per unit of intake with increased forage quality have been previously reported for grazing dairy cows. For example, at similar intake levels, cows grazing pasture in summer produced more $\mathrm{CH}_{4}$ than in spring, and this finding was attributed to grass maturation (Robertson and Waghorn, 2002). More recently, dairy cows grazing LHM swards in summer in Ireland emitted less $\mathrm{CH}_{4}$ per unit of intake than cow grazing HHM swards of poorer nutritive quality (Wims et al., 2010), and dairy cows grazing high digestibility perennial ryegrass produced less $\mathrm{CH}_{4}$ per unit of feed intake than cows offered a TMR of lower digestibility (O'Neill et al., 2011). However, other studies have reported no effect of increased forage quality on $\mathrm{CH}_{4}$ emissions of beef cattle (Pinares-Patiño et al., 2003; Hart et al., 2009; Richmond et al., 2015) and sheep (Molano and Clark, 2008; Sun et al., 2011). The effect of forage quality on methane emissions most likely depends on the extent of contrast in forage quality between treatments among the different studies.

One of the main findings of the present study is that dairy cows offered the LHM pasture emitted less $\mathrm{CH}_{4}$ per unit of milk than the cows offered the HHM pasture. Increasing dairy cow's milk production dilutes their maintenance energy requirements (Johnson and Johnson, 1995), and reduced fiber content of pasture is associated with reduced $\mathrm{CH}_{4}$ production in the rumen (Beauchemin et al., 2008). These results are consistent with the findings of Wims et al. (2010) and indicate that an appropriate pasture management that allows maintaining high pasture quality constitutes an effective, although modest $(\sim 12 \%) \mathrm{CH}_{4}$ mitigation approach. In the present study conducted in late spring, the LHM treatment resulted in better quality pasture than the HHM treatment, the latter being reflective of a very poor grazing management. Whereas undergrazing such as the HHM management of the present experiment would be inefficient in a production setting, it is not unusual in temperate productive systems in the spring. Low productivity of pastures in winter limits stocking rates, and pastures productivity in spring often surpasses what can be efficiently grazed by the animals or conserved. These findings are important within the context of a growing demand for dairy products, together with a concern for the sustainability of food production. The LHM grazing management resulted in higher milk production and reduced methane emissions per unit of product than the HHM grazing management. Diet manipulation through grazing strategies that improve forage quality is a technique that is readily available to farmers, does not require major investments for its implementation, and is most likely viewed as an environmentally friendly strategy, particularly because consumers view livestock production from grazing animals favorably (Morales et al., 2013). Farmers are also likely to be keen about adopting these practices because they enhance animal productivity on a per cow basis.

This study constitutes the second report of measured enteric $\mathrm{CH}_{4}$ emissions from grazing dairy cattle in Chile. The average $\mathrm{CH}_{4}$ emission per unit of estimated feed intake (22.3 g of $\mathrm{CH}_{4} / \mathrm{kg}$ of DMI) and $\mathrm{CH}_{4}$ emission as a percentage of gross energy intake $(7.1 \%)$ obtained in this study were somewhat higher than in previous studies with grazing dairy cattle: $19.3 \mathrm{~g} / \mathrm{kg}$ of DMI and $6.4 \%$ (Wims et al., 2010), $19.2 \mathrm{~g} / \mathrm{kg}$ of DMI and 5.7\% (O'Neill et al., 2011), $20.6 \mathrm{~g} / \mathrm{kg}$ of DMI and $6.2 \%$ (Lassey et al., 1997), and $19.2 \mathrm{~g} / \mathrm{kg}$ of DMI and $6.3 \%$ (Muñoz et al., 2015), respectively. On the other hand and based on 144 studies including cattle, sheep, and goats, Giger-Reverdin et al. (2000) reported an ample variation on $\mathrm{CH}_{4}$ emissions per unit of DMI $(4.9-49.0 \mathrm{~g} / \mathrm{kg}$ of DMI) with an average value of 22.6 $\mathrm{g}$ of $\mathrm{CH}_{4} / \mathrm{kg}$ of DMI. The values reported in this study are within the ranges expected for diets with a high proportion of forage and are similar to the results of Enriquez-Hidalgo et al. (2014), who reported $24.5 \mathrm{~g}$ of $\mathrm{CH}_{4} / \mathrm{kg}$ of DMI for cows fed grass swards in autumn with $423 \mathrm{~g}$ of $\mathrm{NDF} / \mathrm{kg}$ of $\mathrm{DM}$ and $\mathrm{OM}$ digestibility of $780 \mathrm{~g} / \mathrm{kg}$ of DM.

\section{CONCLUSIONS}

The LHM pasture $(\sim 2,100 \mathrm{~kg}$ of DM/ha) used in this study had reduced fiber concentration and increased in vitro digestibility compared with the HHM pasture $(\sim 5,000 \mathrm{~kg}$ of $\mathrm{DM} / \mathrm{ha})$. The better quality pasture increased herbage intake and milk yield and decreased enteric $\mathrm{CH}_{4}$ emissions per kilogram of milk and $\mathrm{CH}_{4}$ energy output per unit of gross energy intake. Total enteric $\mathrm{CH}_{4}$ emissions were not affected by pregrazing herbage mass. These results suggest that grazing management that favors maintaining high-quality pastures during late spring constitutes an effective strategy for moderately decreasing enteric $\mathrm{CH}_{4}$ emissions of dairy cows.

\section{ACKNOWLEDGMENTS}

This research was supported by Fondo Nacional de Desarrollo Científico y Tecnológico (Santiago, Chile) Fondecyt Grant No. 11110410. The authors thank M. E. Martinez (INIA Remehue, Osorno, Chile) for assis- 
tance with the n-alkane laboratory methodology, and F. Lanuza, J. Parga, and A. Torres (INIA Remehue), who provided expertise that greatly assisted the research.

\section{REFERENCES}

Agnew, R. E., T. Yan, J. France, E. Kebreab, and C. Thomas. 2004. Energy requirement and supply. Pages 11-20 in Feed into Milk: A New Applied Feeding System for Dairy Cows. C. Thomas, ed. Nottingham University Press, Nottingham, UK.

Agricultural and Food Research Council. 1993. Energy and Protein Requirements of Ruminants. CAB International, Wallingford, UK.

AOAC International. 1995. Official Methods of Analysis. 16th ed. AOACInternational, Arlington, VA.

Bateman, J. V. 1970. Nutrición animal: Manual de métodos analíticos. Herrero Hermanos Sucesores S. A., Instituto Interamericano de Ciencias Agricolas de la OEA, México.

Beauchemin, K. A., M. Kreuzer, F. O'Mara, and T. A. McAllister. 2008. Nutritional management for enteric methane abatement: A review. Aust. J. Exp. Agric. 48:21-27.

Curran, J., L. Delaby, E. Kennedy, J. P. Murphy, T. M. Boland, and M. O'Donavan. 2010. Sward characteristics, grass dry matter intake and milk production performance are affected by pre-grazing herbage mass and pasture allowance. Livest. Sci. 127:144-154.

Dove, H., and R. W. Mayes. 2006. Protocol for the analysis of n-alkanes and other plant-wax compounds and for their use as markers for quantifying the nutrient supply of large mammalian herbivores. Nat. Protoc. 1:1680-1697.

Enriquez-Hidalgo, D., T. Gilliland, M. H. Deighton, M. O'Donovan, and D. Hennessy. 2014. Milk production and enteric methane emissions by dairy cows grazing fertilized perennial ryegrass pasture with or without inclusion of white clover. J. Dairy Sci. 97:1400-1412.

Giger-Reverdin, S., D. Sauvant, M. Vermorel, and J. Jouany. 2000 Modélisation empirique des facteurs de variation des rejets de méthane par les ruminants. Pages 187-190 in 7emes Rencontres autour des Recherches sur les Ruminants, Paris, France. Institut de l'Elevage, INRA, Paris, France.

Goering, H. K., and P. J. Van Soest. 1970. Forage Fiber Analyses (Apparatus, Reagents, Procedures, and Some Applications). Agriculture Handbook No. 379. ARS-USDA, Washington, DC.

Hammond, K. J., J. L. Burke, J. P. Koolaard, S. Muetzel, C. S. Pinares-Patino, and G. C. Waghorn. 2013. Effects of feed intake on enteric methane emissions from sheep fed fresh white clover (Trifolium repens) and perennial ryegrass (Lolium perenne) forages. Anim. Feed Sci. Technol. 179:121-132.

Hammond, K. J., S. Muetzel, G. C. Waghorn, C. S. Pinares-Patiño, J. L. Burke, and S. O. Hoskin. 2009. The variation in methane emissions from sheep and cattle is not explained by the chemical composition of ryegrass. Proc. N.Z. Soc. Anim. Prod. 69:174-178.

Hart, K. J., J. A. Huntington, R. G. Wilkinson, C. G. Bartram, and L. A. Sinclair. 2015. The influence of grass silage-to-maize silage ratio and concentrate composition on methane emissions, performance and milk composition of dairy cows. Animal 9:983-991.

Hart, K. J., P. G. Martin, P. A. Foley, D. A. Kenny, and T. M. Boland. 2009. Effect of sward dry matter digestibility on methane production, ruminal fermentation, and microbial populations of zero-grazed beef cattle. J. Anim. Sci. 87:3342-3350.

Hoffman, P. C., D. K. Combs, N. M. Brehm, and D. A. Welch. 1997. Performance of lactating dairy cows fed red clover or alfalfa silage. J. Dairy Sci. 80:3308-3315.

Holmes, C. W., C. J. Hoogendoorn, M. P. Ryan, and A. C. P. Chu. 1992. Some effects of herbage composition, as influenced by previous grazing management, on milk production by cows grazing on ryegrass/white clover pastures. 1. Milk production in early spring: Effects of different regrowth intervals during the preceding winter period. Grass Forage Sci. 47:309-315.

Hoogendoorn, C. J., C. W. Holmes, and A. C. P. Chu. 1992. Some effects of herbage composition, as influenced by previous grazing management, on milk production by cows grazing on ryegrass/ white clover pastures. 2. Milk production in late spring/summer: Effects of grazing intensity during the preceding spring period. Grass Forage Sci. 47:316-325.

Hristov, A. N., J. Oh, J. L. Firkins, J. Dijkstra, E. Kebreab, G. Waghorn, H. P. Makkar, A. T. Adesogan, W. Yang, C. Lee, P. J. Gerber, B. Henderson, and J. M. Tricarico. 2013. Special topicsMitigation of methane and nitrous oxide emissions from animal operations: I. A review of enteric methane mitigation options. J. Anim. Sci. 91:5045-5069.

Intergovernmental Panel on Climate Change. 2013. Climate Change 2013: The Physical Science Basis. Contribution of Working Group I to the Fifth Assessment Report of the Intergovernmental Panel on Climate Change. Cambridge University Press, Cambridge, UK.

Janssen, P. H. 2010. Influence of hydrogen on rumen methane formation and fermentation balances through microbial growth kinetics and fermentation thermodynamics. Anim. Feed Sci. Technol. 160:1-22.

Johnson, K. A., and D. E. Johnson. 1995. Methane emissions from cattle. J. Anim. Sci. 73:2483-2492.

Johnson, K. A., H. H. Westberg, J. J. Michal, and M. W. Cossalman. 2007. The SF6 tracer technique: Methane measurement from ruminants. Pages 33-67 in Measuring Methane Production from Ruminants. H. P. S. Makkar and P. E. Vercoe, ed. Springer, Dordrecht, the Netherlands.

Jung, H. G., and M. S. Allen. 1995. Characteristics of plant cell walls affecting intake and digestibility of forages by ruminants. J. Anim. Sci. 73:2774-2790.

Lassey, K. R., M. J. Ulyatt, R. J. Martin, C. F. Walker, and I. D. Shelton. 1997. Methane emissions measured directly from grazing livestock in New Zealand. Atmos. Environ. 31:2905-2914.

Martin, C., D. P. Morgavi, and M. Doreau. 2010. Methane mitigation in ruminants: From microbe to the farm scale. Animal 4:351-365.

Mayes, R. W., C. S. Lamb, and P. M. Colgrove. 1986. The use of dosed and herbage n-alkanes as markers for the determination of herbage intake. J. Agric. Sci. 107:161-170.

McEvoy, M., M. O’Donovan, E. Kennedy, J. P. Murphy, L. Delaby, and T. M. Boland. 2009. Effect of pregrazing herbage mass and pasture allowance on the lactation performance of Holstein-Friesian dairy cows. J. Dairy Sci. 92:414-422.

Molano, G., and H. Clark. 2008. The effect of level of intake and forage quality on methane production by sheep. Aust. J. Exp. Agric 48:219-222.

Morales, R., A. P. S. Aguiar, I. Subiabre, and C. E. Realini. 2013. Beef acceptability and consumer expectations associated with production systems and marbling. Food Qual. Prefer. 29:166-173.

Muñoz, C., S. Hube, J. M. Morales, T. Yan, and E. M. Ungerfeld. 2015. Effects of concentrate supplementation on enteric methane emissions and milk production of grazing dairy cows. Livest. Sci. 175:37-46.

O'Donovan, M., and L. Delaby. 2008. Sward characteristics, grass dry matter intake and milk production performance is affected by timing of spring grazing and subsequent stocking rate. Livest. Sci. 115:158-168.

O'Neill, B. F., M. H. Deighton, B. M. O'Loughlin, F. J. Mulligan, T. M. Boland, M. O'Donovan, and E. Lewis. 2011. Effects of a perennial ryegrass diet or total mixed ration diet offered to springcalving Holstein-Friesian dairy cows on methane emissions, dry matter intake, and milk production. J. Dairy Sci. 94:1941-1951.

Pérez-Prieto, L. A., and R. Delagarde. 2012. Meta-analysis of the effect of pregrazing pasture mass on pasture intake, milk production, and grazing behavior of dairy cows strip-grazing temperate grasslands. J. Dairy Sci. 95:5317-5330.

Pérez-Prieto, L. A., J. L. Peyraud, and R. Delagarde. 2012. Does pregrazing herbage mass really affect herbage intake and milk production of strip-grazing dairy cows? Grass Forage Sci. 68:93-109.

Pinares-Patiño, C. S., R. Baumont, and C. Martin. 2003. Methane emissions by Charolais cows grazing a monospecific pasture of timothy at four stages of maturity. Can. J. Anim. Sci. 83:769-777.

Ribeiro Filho, H. M. N., R. Delagarde, and J. L. Peyraud. 2005. Herbage intake and milk yield of dairy cows grazing perennial rye- 
grass swards or white clover/perennial ryegrass swards at low- and medium-herbage allowances. Anim. Feed Sci. Technol. 119:13-27.

Richmond, A. S., A. R. G. Wylie, A. S. Laidlaw, and F. O. Lively 2015. Methane emissions from beef cattle grazing on semi-natural upland and improved lowland grasslands. Animal 9:130-137.

Robertson, L. J., and G. C. Waghorn. 2002. Dairy industry perspectives on methane emissions and production from cattle fed pasture or total mixed rations in New Zealand. Proc. N.Z. Soc. Anim. Prod. 62:213-218.

Stakelum, G., and P. Dillon. 2004. The effect of herbage mass and allowance on herbage intake, diet composition and ingestive behaviour of dairy cows. Ir. J. Agric. Food Res. 43:17-30.

Sun, X. Z., S. O. Hoskin, S. Muetzel, G. Molano, and H. Clark. 2011. Effects of forage chicory (Cichorium intybus) and perennial rye- grass (Lolium perenne) on methane emissions in vitro and from sheep. Anim. Feed Sci. Technol. 166-167:391-397.

Tyrrell, H. F., and J. T. Reid. 1965. Prediction of the energy value of cow's milk. J. Dairy Sci. 48:1215-1223.

Wims, C. M., M. H. Deighton, E. Lewis, B. O'Loughlin, L. Delaby, T. M. Boland, and M. O'Donovan. 2010. Effect of pregrazing herbage mass on methane production, dry matter intake, and milk production of grazing dairy cows during the mid-season period. J. Dairy Sci. 93:4976-4985.

Yan, T., R. E. Agnew, F. J. Gordon, and M. G. Porter. 2000. Prediction of methane energy output in dairy and beef cattle offered grass silage-based diets. Livest. Prod. Sci. 64:253-263. 